\title{
Agri-food market of the region: strategic analysis and development prospects
}

\author{
Anzor Gyatov ${ }^{1, *}$, Zarina Soskiyeva ${ }^{2}$, Madina Marzhokhova ${ }^{1}$, Anzor Shardanov ${ }^{1}$, and \\ Oksana Bagova ${ }^{1}$ \\ ${ }^{1}$ Kabardino - Balkarian State Agricultural University named after V.M. Kokov, Lenin Avenue, 1V, \\ 360030 Nalchik, Russia \\ ${ }^{2}$ Gorsky State Agrarian University, Vladikavkaz, Russia
}

\begin{abstract}
The agri-food market is distinguished by a high degree of dependence on external factors, such as climatic and weather conditions, uneven supply and demand for agricultural products due to the seasonality of production, which explains the dynamism and instability of this market segment. [1] Due to the indicated reasons, the process of current and strategic planning, analysis, determination of development prospects, is an integral part of agricultural production. The article studies the state of the agri-food market of the Kabardino-Balkarian Republic on the scale of the North Caucasian Federal District. The dynamics of the indicators of the produced crop and livestock products in the context of the regions of the NCFD are considered and analyzed, the comparative characteristics of the analyzed values are performed. The results of the analytical study made it possible to build a SWOT analysis model, which identifies the strengths and weaknesses of the agri-food market of the Kabardino-Balkarian Republic, as well as the opportunities and threats of its development.
\end{abstract}

\section{Introduction}

The regional food market is, on the one hand, a subsystem of the national food market, and on the other hand, it acts as a subsystem of the regional social-and-economic system [2].

The relevance of the study is due to the importance of the agri-food market in the region, not only at the level of the subject, but also in general for the country's macroeconomic development, national food security.

The purpose of this study is to analyze the current state of the agri-food market of the Kabardino-Balkarian Republic in terms of assessing its strengths and weaknesses, as well as opportunities and threats, in order to determine the most favorable prospects for the development of the regional agri-food market.

\footnotetext{
* Corresponding author: gyatov.anzor@bk.ru
} 


\section{Materials and Methods}

The information base for the study of the regional agri-food market was the data of the Federal State Statistics Service, as well as literary sources of domestic and foreign authors.

The work found the application of the monographic research method, as well as such methods of cognition as: analysis, synthesis, generalization, the method of economic comparison and the method of SWOT analysis.

\section{Results and discussion}

To determine the main directions of the strategic development of the regional agri-food market, a comprehensive diagnosis of the state of the agrarian market of the region at the present time is required.

The efficiency and efficiency of agricultural production is largely determined by the provision of the regional agro-industrial complex with a material and technical base [3], table 1 shows the dynamics of changes in indicators characterizing the state of fixed assets in agriculture in the Kabardino-Balkarian Republic.

Table 1. Fixed assets of the Kabardino-Balkarian Republic and the efficiency of their use.

\begin{tabular}{|c|c|c|c|c|c|c|}
\hline \multirow{2}{*}{ Indicators } & \multicolumn{5}{|c|}{ Year } & \multirow{2}{*}{$\begin{array}{c}2019 \text { to } 2015 \\
\text { in } \%\end{array}$} \\
\hline & 2015 & 2016 & 2017 & 2018 & 2019 & \\
\hline $\begin{array}{l}\text { The cost of fixed assets in } \\
\text { agriculture, RUR mln }\end{array}$ & 27344 & 38643 & 43540 & 42392 & 36992 & 135.3 \\
\hline $\begin{array}{l}\text { New fixed assets } \\
\text { commissioned, RUR mln }\end{array}$ & 4302.7 & $\begin{array}{c}10110 . \\
2\end{array}$ & 738.0 & 1305.1 & 746.0 & 17.3 \\
\hline $\begin{array}{l}\text { Fixed asset depreciation } \\
\text { value, } \%\end{array}$ & 30.4 & 40.6 & 46.0 & 47.4 & 47.3 & 155.5 \\
\hline Fixed assets renewal ratio, $\%$ & 9.8 & 25.7 & 6.9 & 11.5 & 6.7 & 68.4 \\
\hline $\begin{array}{lll}\begin{array}{l}\text { Fixed } \\
\text { ratio, } \%\end{array} & \text { assets } & \text { liquidation } \\
\end{array}$ & 0.4 & 0.5 & 0.8 & 1.1 & 0.4 & 100 \\
\hline Return on assets of agriculture & 1.43 & 1.13 & 1.04 & 1.16 & 1.46 & 102.1 \\
\hline Capital intensity of agriculture & 0.70 & 0.88 & 0.96 & 0.86 & 0.69 & 98.6 \\
\hline
\end{tabular}

Source: compiled by the author based on the data of [4].

The data in Table 1 indicate the unsatisfactory state of fixed assets of agriculture in the Kabardino-Balkarian Republic, in particular, a high degree of depreciation, a low level of renewal of fixed assets, the exception is the rate of return on assets, which has a slight positive trend over the analyzed period.

The presented information indicates that the material and technical support of agroindustrial production is the "weak" side of the regional agri-food market of the republic. The result of this state of affairs in the industry is: underdevelopment of the infrastructure of the agro-industrial complex, often extensive forms of organization of work, due to a lack of equipment, as well as a reduction in acreage (Table 2).

Table 2. The structure of the cultivated areas of the Kabardino-Balkarian Republic.

\begin{tabular}{|c|c|c|c|c|c|c|c|}
\hline \multirow{2}{*}{ Indicators } & \multicolumn{5}{|c|}{ Year } & $\begin{array}{c}2019 \text { to } \\
2010 \text { in } \\
\%\end{array}$ \\
\cline { 2 - 6 } & 2010 & 2015 & 2016 & 2017 & 2018 & 2019 & \\
\hline $\begin{array}{l}\text { Sown area, } \\
\text { agricultural crops, } \\
\text { th ha }\end{array}$ & 287.9 & 282.6 & 282.8 & 283.7 & 283.0 & 281.8 & 97.8 \\
\hline
\end{tabular}


Table 2. Continued.

\begin{tabular}{|c|c|c|c|c|c|c|c|}
\hline \multicolumn{8}{|c|}{$\begin{array}{l}\text { The structure of sown areas of agricultural crops in farms of all categories, as a } \\
\text { percentage of the total sown area, } \%\end{array}$} \\
\hline $\begin{array}{l}\text { cereal and } \\
\text { leguminous crops }\end{array}$ & 175.3 & 207.8 & 207.7 & 210.7 & 209.1 & 212.1 & 121.0 \\
\hline industrial crops & 44.1 & 26.8 & 30.0 & 27.8 & 31.0 & 28.5 & 64.6 \\
\hline $\begin{array}{ll}\text { potatoes } & \text { and } \\
\text { vegetable } & \text { and } \\
\text { melon crops } & \end{array}$ & 30.8 & 29.1 & 27.9 & 28.5 & 24.7 & 23.7 & 76.9 \\
\hline forage crops & 37.7 & 18.9 & 17.2 & 16.7 & 18.2 & 17.5 & 46.4 \\
\hline
\end{tabular}

Source: compiled by the author based on the data of [4].

The data in Table 2 indicate, in general, a decrease in sown areas over the past 10 years in the KBR by $2.2 \%$. However, it should be noted that positive dynamics for the analyzed period is noted for grain and leguminous crops - an increase in acreage by $21 \%$. For the rest of agricultural crops, there is a decrease in sown areas: industrial crops by $35.4 \%$, potatoes and vegetable and melon crops - $23.1 \%$, fodder crops $-53.6 \%$. Thus, it can be concluded that cereals and leguminous crops prevail in the region's crop production.

For the most vivid picture of the volume of agricultural products produced on the scale of the KBR, let us compare these indicators for the regions of the North Caucasian Federal District (Table 3).

Table 3. Agricultural products in farms of all categories (in actual prices), RUR mln.

\begin{tabular}{|c|c|c|c|c|c|c|c|c|}
\hline \multirow[b]{2}{*}{ Indicators } & \multicolumn{6}{|c|}{ Year } & \multirow[b]{2}{*}{$\begin{array}{l}2019 \\
\text { to } \\
2010 \\
\text { in } \%\end{array}$} & \multirow{2}{*}{$\begin{array}{c}\text { Dama } \\
\text { ge } \\
\text { locati } \\
\text { on } \\
\text { in the } \\
\text { Russi } \\
\text { an } \\
\text { Feder } \\
\text { ation }\end{array}$} \\
\hline & 2010 & 2015 & 2016 & 2017 & 2018 & 2019 & & \\
\hline $\mathrm{RF}$ & 2462187 & $\begin{array}{c}479461 \\
5 \\
\end{array}$ & $\begin{array}{c}511235 \\
6 \\
\end{array}$ & $\begin{array}{c}510947 \\
5 \\
\end{array}$ & $\begin{array}{c}534877 \\
7 \\
\end{array}$ & $\begin{array}{c}590795 \\
5 \\
\end{array}$ & 239.9 & - \\
\hline NCFD & 197873 & 384914 & 428066 & 436752 & 461495 & $\begin{array}{c}493569 . \\
8\end{array}$ & 249.4 & 5 \\
\hline $\begin{array}{l}\text { The } \\
\text { Republic of } \\
\text { Dagestan }\end{array}$ & 47410 & 94478 & 108473 & 118960 & 124371 & $\begin{array}{c}132923 . \\
2\end{array}$ & 280.4 & 14 \\
\hline $\begin{array}{l}\text { The } \\
\text { Republic of } \\
\text { Ingushetia }\end{array}$ & 3231 & 6885 & 8518 & 9031 & 10392 & 10812.1 & 334.6 & 70 \\
\hline $\begin{array}{l}\text { Kabardino- } \\
\text { Balkar } \\
\text { Republic }\end{array}$ & 23588 & 37920 & 42424 & 45710 & 49385 & 54133.1 & 229.5 & 35 \\
\hline $\begin{array}{l}\text { Karachay- } \\
\text { Cherkess } \\
\text { Republic }\end{array}$ & 15040 & 26032 & 26802 & 27581 & 29513 & 33334.8 & 221.6 & 53 \\
\hline $\begin{array}{l}\text { Republic } \\
\text { Northern } \\
\text { Ossetia- } \\
\text { Alania } \\
\end{array}$ & 16910 & 23210 & 22165 & 22291 & 24198 & 29990.5 & 177.4 & 54 \\
\hline $\begin{array}{l}\text { The Chechen } \\
\text { Republic }\end{array}$ & 10893 & 17549 & 21123 & 25997 & 27778 & 32420.9 & 297.6 & 52 \\
\hline $\begin{array}{l}\text { Stavropol } \\
\text { Territory }\end{array}$ & 80801 & 178840 & 198563 & 187182 & 195858 & $\begin{array}{c}199955 . \\
1\end{array}$ & 247.5 & 6 \\
\hline
\end{tabular}

Source: compiled by the author based on the data of [5]. 
The volumes of agricultural products for the analyzed period tended to grow in all regions of the North Caucasus Federal District, for example, in the Republic of Ingushetia, the volume of agricultural production increased more than 3 times, in other regions more than 2 times, with the exception of the Republic of North Ossetia-Alania, where the volume of production agriculture increased 1.77 times. However, if we consider the volumes of agricultural products produced on a national scale, it should be noted that the KBR ranks 35th in the country, yielding in this indicator to the Stavropol Territory (6th place) and the Republic of Dagestan (14th place) from the regions of the NCFDt.

Let us consider the production volumes of the main agricultural crops in the regions of the NCFD, for the analysis and comparison of the indicators of the Kabardino-Balkarian Republic on the scale of the federal district (Table 4).

Table 4. Gross harvest (thousand tons) of major agricultural crops in all categories of farms in the NCFD regions.

\begin{tabular}{|c|c|c|c|c|c|}
\hline \multirow{2}{*}{ Crops } & \multicolumn{4}{|c|}{ Year } & \multirow{2}{*}{$\begin{array}{c}2019 \text { to } \\
2010 \text { in } \\
\%\end{array}$} \\
\hline & 2010 & 2017 & 2018 & 2019 & \\
\hline \multicolumn{6}{|c|}{ Grain (in weight after processing), th tons } \\
\hline NCFD & 8456.8 & 13261.1 & 11980.3 & 11424.8 & 135.1 \\
\hline The Republic of Dagestan & 211.1 & 414.9 & 359.5 & 385.0 & 182.4 \\
\hline The Republic of Ingushetia & 43.9 & 47.4 & 89.4 & 40.7 & 92.7 \\
\hline Kabardino-Balkar Republic & 644.0 & 1157.3 & 1128.1 & 1136.1 & 176.4 \\
\hline Karachay-Cherkess Republic & 143.7 & 476.1 & 437.9 & 493.9 & 343.7 \\
\hline $\begin{array}{lll}\text { Republic } & \text { Northern } & \text { Ossetia- } \\
\text { Alania } & & \\
\end{array}$ & 399.7 & 636.2 & 763.8 & 791.2 & 197.9 \\
\hline The Chechen Republic & 124.6 & 422.0 & 268.4 & 177.7 & 142.6 \\
\hline Stavropol Territory & 6889.7 & 10107.2 & 8933.2 & 8400.2 & 121.9 \\
\hline \multicolumn{6}{|c|}{ Sunflower seeds, th $t$} \\
\hline NCFD & 388.0 & 684.2 & 594.6 & 560.2 & 144.4 \\
\hline The Republic of Dagestan & 3.8 & 9.1 & 8.3 & 8.4 & 221.1 \\
\hline The Republic of Ingushetia & 3.4 & 1.9 & 3.3 & 0.2 & 5.9 \\
\hline Kabardino-Balkar Republic & 43.2 & 28.4 & 32.9 & 26.1 & $60.4-2$ \\
\hline Karachay-Cherkess Republic & 7.0 & 15.5 & 17.0 & 15.0 & 214.3 \\
\hline $\begin{array}{lll}\text { Republic } & \text { Northern } & \text { Ossetia- } \\
\text { Alania } & & \\
\end{array}$ & 1.2 & 3.6 & 2.4 & 1.4 & 116.7 \\
\hline The Chechen Republic & 5.0 & 24.8 & 4.4 & 2.3 & 46.0 \\
\hline Stavropol Territory & 324.4 & 600.9 & 526.3 & 506.9 & 156.3 \\
\hline \multicolumn{6}{|c|}{ Potatoes, tht } \\
\hline NCFD & 1063.2 & 1065.9 & 1064.1 & 1029.8 & 96.9 \\
\hline The Republic of Dagestan & 295.5 & 357.0 & 356.3 & 353.5 & 119.6 \\
\hline The Republic of Ingushetia & 29.5 & 49.8 & 37.3 & 33.0 & 111.9 \\
\hline Kabardino-Balkar Republic & 200.8 & 184.9 & 182.9 & 196.0 & 97.6 \\
\hline Karachay-Cherkess Republic & 165.6 & 143.9 & 123.8 & 107.9 & 65.2 \\
\hline $\begin{array}{l}\text { Republic Northern } \text { Ossetia- } \\
\text { Alania }\end{array}$ & 119.4 & 62.7 & 99.3 & 89.2 & 74.7 \\
\hline The Chechen Republic & 21.8 & 38.5 & 32.1 & 32.7 & 150.0 \\
\hline Stavropol Territory & 230.5 & 229.1 & 232.5 & 217.6 & 94.4 \\
\hline \multicolumn{6}{|c|}{ Vegetables, th $t$} \\
\hline NCFD & 1632.6 & 2447.6 & 2405.1 & 2442.6 & 149.6 \\
\hline The Republic of Dagestan & 973.6 & 1451.7 & 1438.5 & 1432.1 & 147.1 \\
\hline The Republic of Ingushetia & 1.8 & 2.8 & 3.9 & 5.5 & 305.6 \\
\hline Kabardino-Balkar Republic & 315.0 & 498.9 & 470.4 & 404.4 & 128.4-2 \\
\hline
\end{tabular}


Table 4. Continued.

\begin{tabular}{|l|c|c|c|c|c|}
\hline Karachay-Cherkess Republic & 56.3 & 79.3 & 77.2 & 73.3 & 130.2 \\
\hline $\begin{array}{l}\text { Republic Northern Ossetia- } \\
\text { Alania }\end{array}$ & 35.3 & 19.3 & 28.4 & 31.0 & 87.8 \\
\hline The Chechen Republic & 25.2 & 75.2 & 75.2 & 130.3 & 517.1 \\
\hline Stavropol Territory & 225.4 & 320.5 & 311.6 & 365.9 & 162.3 \\
\hline \multicolumn{5}{|c|}{ Fruits and berries, th t } \\
\hline NCFD & 268.4 & 487.5 & 557.2 & 703.8 & 262.2 \\
\hline The Republic of Dagestan & 107.6 & 157.7 & 161.1 & 173.3 & 161.1 \\
\hline The Republic of Ingushetia & 0.8 & 10.9 & 20.7 & 25.6 & 3200.0 \\
\hline Kabardino-Balkar Republic & $\mathbf{9 0 . 4}$ & $\mathbf{2 1 5 . 2}$ & $\mathbf{2 5 7 . 2}$ & $\mathbf{3 4 9 . 5}$ & $\mathbf{3 8 6 . 6 - 1}$ \\
\hline Karachay-Cherkess Republic & 3.4 & 7.5 & 10.3 & 15.0 & 441.2 \\
\hline $\begin{array}{l}\text { Republic Northern Ossetia- } \\
\text { Alania }\end{array}$ & 14 & 18.9 & 18.8 & 43.2 & 308.6 \\
\hline The Chechen Republic & 12.0 & 17.8 & 20.3 & 20.9 & 174.2 \\
\hline Stavropol Territory & 39.3 & 59.6 & 68.6 & 76.4 & 194.4 \\
\hline
\end{tabular}

Source: compiled by the author based on the data of [5].

The production of grain and leguminous crops for the analyzed period in the KBR increased by $76.4 \%$ and in 2019 amounted to $1,136.1$ thousand tons, some role in this was played by an increase in acreage for these crops by $21 \%$, in this product category in terms of production, the Kabardino-Balkarian Republic from the regions of the North Caucasus Federal District is second only to the Stavropol Territory, where grain production in 2019 amounted to 8400.2 th t. In terms of sunflower production, the leading place in the North Caucasus Federal District belongs to the Stavropol Territory - 506.9 thousand tons in 2019, followed by Kabardino-Balkaria - 26.1 thousand tons, while it should be noted that the reduction in sunflower production for the analyzed period in the KBR was 39, 6\%. The largest gross potato harvest in 2019 in the North Caucasus Federal District belongs to the following regions: the Republic of Dagestan - 353.5 th t, the Stavropol Territory - 217.6 th $t$ and the KBR - 196.0 th $\mathrm{t}$. In terms of vegetable production, the Kabardino-Balkarian Republic from the regions of the North Caucasus Federal District is second only to the Republic of Dagestan - 1432.1 th t and 404.4 th $t$, respectively. The production of fruit and berry crops in the KBR in 2019 amounted to 349.5 th t, for 2010-2019, the production of this product category increased almost 4 times. It should be noted that the production of fruit and berry crops is the most developed branch of agricultural production in the Kabardino-Balkarian Republic, providing a leading position not only among the regions of the North Caucasus Federal District, but also in the Russian Federation, since in the production of fruits and berries the KBR is second only to the Krasnodar Territory in the country, where the gross product collections in 2019 amounted to 497.6 th $\mathrm{t}$. In general, it should be noted that in recent years, the intensification of import substitution, the domestic fruit and berry sector shows positive dynamics and becomes more and more attractive [6].

Table 5. Productivity of the main agricultural crops in all categories of farms in the Kabardino-Balkarian Republic and the North Caucasian Federal District, c/ha.

\begin{tabular}{|c|c|c|c|c|c|}
\hline \multirow{2}{*}{ Crops } & \multicolumn{4}{|c|}{ Year } & \multirow{2}{*}{$\begin{array}{c}2019 \\
\text { to } \\
2010 \\
\text { in } \%\end{array}$} \\
\hline & 2010 & 2017 & 2018 & 2019 & \\
\hline \multicolumn{6}{|c|}{ Kabardino-Balkar Republic } \\
\hline $\begin{array}{l}\text { Grain (weight } \\
\text { after } \\
\text { enhancement) }\end{array}$ & 37.4 & 56.3 & 54.1 & 54.8 & 146.5 \\
\hline
\end{tabular}


Table 5. Continued.

\begin{tabular}{|c|c|c|c|c|c|}
\hline $\begin{array}{c}\text { Sunflower } \\
\text { seeds }\end{array}$ & 14.4 & 16.5 & 18.8 & 18.4 & 127.8 \\
\hline Potatoes & 162 & 204 & 217 & 236 & 145.7 \\
\hline Vegetables & 175 & 259 & 290 & 260 & 148.6 \\
\hline $\begin{array}{c}\text { Fruits and } \\
\text { berries }\end{array}$ & 119.0 & 200.1 & 215.9 & 249.4 & 209.6 \\
\hline \multicolumn{5}{|c|}{ North Caucasian Federal District } \\
\hline $\begin{array}{c}\text { Grain (weight } \\
\text { after } \\
\text { enhancement) }\end{array}$ & 32.2 & 41.9 & 37.8 & 35.9 & 111.5 \\
\hline $\begin{array}{c}\text { Sunflower } \\
\text { seeds }\end{array}$ & 13.1 & 17.6 & 16.5 & 17.0 & 129.8 \\
\hline $\begin{array}{c}\text { Potatoes } \\
\text { Vegetables }\end{array}$ & 128 & 170 & 173 & 176 & 137.5 \\
\hline $\begin{array}{c}\text { Fruits and } \\
\text { berries }\end{array}$ & 60.8 & 113.0 & 122.7 & 143.5 & 236.1 \\
\hline
\end{tabular}

Source: compiled by the author based on the data of [5].

Comparison of yield indicators for the Kabardino-Balkarian Republic and values for the North Caucasian Federal District (Table 5) testifies in favor of the KBR, since practically for all years and for all categories of crops, yield variations in the republic exceed those for the NCFD. These circumstances are due to a number of factors, in particular, favorable natural and climatic conditions; the use of modern technologies in the organization of agricultural production, for example, the system of intensive gardening; the use of mineral fertilizers and modern plant protection products; the use of quality seeds, high-performance varieties and crops; increasing soil fertility.

Table 6. Dynamics of the number of livestock by regions of the NCFD.

\begin{tabular}{|c|c|c|c|c|c|c|c|c|}
\hline & \multicolumn{3}{|c|}{ Livestock (th animals) } & \multirow{2}{*}{$\begin{array}{l}\text { Place in } \\
\text { RF in } \\
2019\end{array}$} & \multicolumn{3}{|c|}{$\begin{array}{c}\text { Livestock of sheep and } \\
\text { goats } \\
\text { (th animals) }\end{array}$} & \multirow{2}{*}{$\begin{array}{l}\text { Place } \\
\text { in RF } \\
\text { in } \\
2019\end{array}$} \\
\hline & 2017 & 2018 & 2019 & & 2017 & 2018 & 2019 & \\
\hline NCFD & 2126.4 & 2091.9 & 2087.6 & 5 & $\begin{array}{c}8952 . \\
8\end{array}$ & $\begin{array}{c}8359 . \\
5\end{array}$ & $\begin{array}{c}8314 . \\
7\end{array}$ & 1 \\
\hline $\begin{array}{l}\text { The } \\
\text { Republic of } \\
\text { Dagestan }\end{array}$ & 1004.0 & 960.5 & 952.1 & 2 & $\begin{array}{c}5339 . \\
5\end{array}$ & $\begin{array}{c}4743 . \\
8\end{array}$ & $\begin{array}{c}4647 . \\
1\end{array}$ & 1 \\
\hline $\begin{array}{l}\text { The } \\
\text { Republic of } \\
\text { Ingushetia }\end{array}$ & 57.0 & 65.4 & 67.2 & 64 & 152.2 & 198.3 & 216.2 & 20 \\
\hline $\begin{array}{l}\text { Kabardino- } \\
\text { Balkar } \\
\text { Republic }\end{array}$ & 265.7 & 265.1 & 268.6 & 22 & 364.0 & 375.9 & 383.9 & 13 \\
\hline $\begin{array}{l}\text { Karachay- } \\
\text { Cherkess } \\
\text { Republic } \\
\end{array}$ & 157.5 & 157.4 & 160.7 & 45 & $\begin{array}{c}1080 . \\
1\end{array}$ & $\begin{array}{c}1094 . \\
4\end{array}$ & $\begin{array}{c}1137 . \\
8\end{array}$ & 6 \\
\hline $\begin{array}{l}\text { Republic } \\
\text { Northern } \\
\text { Ossetia- } \\
\text { Alania } \\
\end{array}$ & 83.4 & 91.2 & 92.7 & 59 & 58.9 & 74.8 & 98.7 & 34 \\
\hline $\begin{array}{l}\text { The Chechen } \\
\text { Republic }\end{array}$ & 239.7 & 251.5 & 252.8 & 24 & 248.3 & 238.5 & 265.4 & 18 \\
\hline $\begin{array}{l}\text { Stavropol } \\
\text { Territory }\end{array}$ & 319.1 & 300.7 & 293.5 & 20 & $\begin{array}{c}1709 . \\
9\end{array}$ & $\begin{array}{c}1633 . \\
7\end{array}$ & $\begin{array}{c}1565 . \\
6 \\
\end{array}$ & 3 \\
\hline
\end{tabular}

Source: compiled by the author based on the data of [5]. 
When analyzing the regional agri-food market, along with the indicators of sown areas, gross harvests and crop yields, indicators characterizing the livestock sector of agriculture in the region are of great importance. The basis of animal husbandry is the breeding of cattle, sheep and goats.

The data in Table 6 indicate a positive trend in the Kabardino-Balkarian Republic for the analyzed period, both in the number of cattle $-1.1 \%$ and in the number of sheep and goats $-5.5 \%$. In terms of the number of cattle in 2019 in the NCFD, the leading positions belong to the Republic of Dagestan - 952.1 th animals, the Stavropol Territory - 293.5 th animals and the Kabardino-Balkarian Republic - 268.6 th animals. The three leaders in terms of the number of sheep and goats among the regions of the NCFD are as follows: The Republic of Dagestan - 4647.1 th animals, the Stavropol Territory - 1565.6 th animals and the Karachay-Cherkess Republic - 1137.8 th animals, then the KBR - 383.9 th animals. In general, it should be noted, in contrast to crop production, animal husbandry is a weaker competitive position of the Kabardino-Balkarian Republic. Further strengthening of the competitive advantages of the industry requires an increase in the productivity of livestock and poultry (Table 7).

Table 7. Livestock production in the NCFD.

\begin{tabular}{|c|c|c|c|c|c|}
\hline \multirow[b]{2}{*}{ Crops } & \multicolumn{4}{|c|}{ Year } & \multirow[b]{2}{*}{$\begin{array}{l}\text { Place in } \\
\text { RF in } \\
2019\end{array}$} \\
\hline & 2017 & 2018 & 2019 & $\begin{array}{c}2019 \text { to } \\
2017 \text { in } \\
\%\end{array}$ & \\
\hline \multicolumn{6}{|c|}{ Production of livestock and poultry for slaughter (slaughter weight), th $t$} \\
\hline NCFD & 655.1 & 681.9 & 706.9 & 107.9 & 7 \\
\hline $\begin{array}{l}\text { The Republic of } \\
\text { Dagestan }\end{array}$ & 143.6 & 148.4 & 150.8 & 105.0 & 23 \\
\hline $\begin{array}{l}\text { The Republic of } \\
\text { Ingushetia }\end{array}$ & 3.4 & 3.7 & 4.0 & 117.6 & 76 \\
\hline $\begin{array}{l}\text { Kabardino- } \\
\text { Balkar Republic }\end{array}$ & 73.9 & 70.5 & 72.1 & 97.6 & 43 \\
\hline $\begin{array}{l}\text { Karachay- } \\
\text { Cherkess } \\
\text { Republic } \\
\end{array}$ & 29.2 & 27.9 & 31.2 & 106.8 & 57 \\
\hline $\begin{array}{l}\text { Republic } \\
\text { Northern } \\
\text { Ossetia-Alania }\end{array}$ & 20.9 & 19.2 & 23.0 & 110.0 & 64 \\
\hline $\begin{array}{l}\text { The Chechen } \\
\text { Republic }\end{array}$ & 23.7 & 23.5 & 24.6 & 103.8 & 63 \\
\hline $\begin{array}{l}\text { Stavropol } \\
\text { Territory }\end{array}$ & 360.4 & 388.5 & 401.3 & 111.3 & 5 \\
\hline \multicolumn{6}{|c|}{ Milk production, th $t$} \\
\hline NCFD & 2618.4 & 2627.2 & 2694.9 & 102.9 & 5 \\
\hline $\begin{array}{l}\text { The Republic of } \\
\text { Dagestan }\end{array}$ & 875.6 & 892.7 & 913.3 & 104.3 & 7 \\
\hline $\begin{array}{l}\text { The Republic of } \\
\text { Ingushetia }\end{array}$ & 93.1 & 98.4 & 107.4 & 115.4 & 66 \\
\hline $\begin{array}{l}\text { Kabardino- } \\
\text { Balkar Republic }\end{array}$ & 490.5 & 499.2 & 514.4 & 104.9 & 24 \\
\hline $\begin{array}{l}\text { Karachay- } \\
\text { Cherkess } \\
\text { Republic }\end{array}$ & 185.4 & 187.0 & 193.1 & 104.2 & 47 \\
\hline $\begin{array}{l}\text { Republic } \\
\text { Northern } \\
\text { Ossetia-Alania }\end{array}$ & 144.5 & 155.0 & 167.9 & 116.2 & 53 \\
\hline $\begin{array}{l}\text { The Chechen } \\
\text { Republic }\end{array}$ & 286.9 & 285.8 & 290.7 & 101.3 & 40 \\
\hline $\begin{array}{l}\text { Stavropol } \\
\text { Territory }\end{array}$ & 542.5 & 509.1 & 507.9 & 93.6 & 25 \\
\hline
\end{tabular}


Table 7. Continued.

\begin{tabular}{|c|c|c|c|c|c|}
\hline \multicolumn{6}{|c|}{ Egg production, mln pcs. } \\
\hline NCFD & 1587.1 & 1607.2 & 1567.7 & 98.8 & 7 \\
\hline $\begin{array}{l}\text { The Republic of } \\
\text { Dagestan }\end{array}$ & 255.0 & 245.0 & 246.1 & 96.5 & 44 \\
\hline $\begin{array}{l}\text { The Republic of } \\
\text { Ingushetia }\end{array}$ & 14.2 & 19.7 & 23.3 & 164.1 & 73 \\
\hline $\begin{array}{l}\text { Kabardino- } \\
\text { Balkar Republic }\end{array}$ & 229.5 & 229.8 & 230.1 & 100.3 & 45 \\
\hline $\begin{array}{l}\text { Karachay- } \\
\text { Cherkess } \\
\text { Republic }\end{array}$ & 81.3 & 83.7 & 82.5 & 101.5 & 65 \\
\hline $\begin{array}{l}\text { Republic } \\
\text { Northern } \\
\text { Ossetia-Alania }\end{array}$ & 70.5 & 69.2 & 69.2 & 98.2 & 66 \\
\hline $\begin{array}{l}\text { The Chechen } \\
\text { Republic }\end{array}$ & 146.3 & 131.4 & 122.7 & 83.9 & 56 \\
\hline $\begin{array}{l}\text { Stavropol } \\
\text { Territory }\end{array}$ & 790.4 & 828.3 & 793.8 & 100.4 & 25 \\
\hline \multicolumn{6}{|c|}{ Wool production, $t$} \\
\hline NCFD & 24258 & 24181 & 21922 & 90.4 & 1 \\
\hline $\begin{array}{l}\text { The Republic of } \\
\text { Dagestan }\end{array}$ & 15061 & 15481 & 13126 & 87.2 & 1 \\
\hline $\begin{array}{l}\text { The Republic of } \\
\text { Ingushetia }\end{array}$ & 332 & 343 & 428 & 128.9 & 19 \\
\hline $\begin{array}{l}\text { Kabardino- } \\
\text { Balkar Republic }\end{array}$ & 976 & 1000 & 1033 & 105.8 & 10 \\
\hline $\begin{array}{l}\text { Karachay- } \\
\text { Cherkess } \\
\text { Republic } \\
\end{array}$ & 1403 & 1342 & 1380 & 98.4 & 8 \\
\hline $\begin{array}{l}\text { Republic } \\
\text { Northern } \\
\text { Ossetia-Alania }\end{array}$ & 95 & 104 & 114 & 120.0 & 35 \\
\hline $\begin{array}{l}\text { The Chechen } \\
\text { Republic }\end{array}$ & 595 & 575 & 546 & 91.8 & 17 \\
\hline $\begin{array}{l}\text { Stavropol } \\
\text { Territory }\end{array}$ & 5823 & 5336 & 5294 & 90.9 & 3 \\
\hline
\end{tabular}

Source: compiled by the author based on the data of [5].

The data in Table 7 indicate a positive trend in the production of livestock products for the analyzed period in the Kabardino-Balkarian Republic: milk production - $4.9 \%$, egg production $-0.3 \%$, wool production $-5.8 \%$, with the exception of livestock and poultry production. for slaughter, where there was a decrease in the indicator by $2.4 \%$.

In general, it should be noted that in terms of crop and livestock production, the Kabardino-Balkarian Republic is one of the top three in the North Caucasian Federal District, along with the Stavropol Territory and the Republic of Dagestan. However, for the objectivity of the conclusions, it is necessary to take into account that the number of people employed in agriculture in the Stavropol Territory exceeds the number of people employed in agriculture in the KBR by 2.5 times; in the Republic of Dagestan - 3.3 times. The sown area of the Stavropol Territory is 11.2 times, and the area of the Republic of Dagestan is 1.2 times higher than the same indicators for the Kabardino-Balkarian Republic. It should also be noted that the total land area of the Stavropol Territory is 6616.0 th ha, the Republic of Dagestan - 5027.0 thousand hectares, and the Kabardino-Balkarian Republic - 1247.0 th ha.

To assess the state of the regional market for agricultural products for strengths and weaknesses, as well as to identify promising areas of development - opportunities and potential threats, the SWOT analysis method can be used [7] (Table 8). 
Table 8. SWOT analysis of the development of the agri-food market of the Kabardino-Balkarian Republic.

\begin{tabular}{|c|c|}
\hline Strengths: & Weaknesses \\
\hline $\begin{array}{l}\text { - favorable natural and climatic conditions and } \\
\text { geographical location for agricultural } \\
\text { production; } \\
\text { - the market of fruit and berry products } \\
\text { occupies a leading position on a national scale; } \\
\text { - the use of modern, innovative technologies in } \\
\text { production (intensive gardening, modern } \\
\text { vegetable and fruit storage facilities); } \\
\text { - developed infrastructure network in the region } \\
\text { (gasification, electrification, water supply } \\
\text { systems; transport and logistics networks); } \\
\text { - human resources, characterized by the } \\
\text { presence in the region of specialized secondary } \\
\text { and higher educational institutions for the } \\
\text { training of specialists in the field of the agro- } \\
\text { industrial complex. }\end{array}$ & $\begin{array}{l}\text { - reduction of acreage; } \\
\text { - insufficient level of technical equipment of } \\
\text { agricultural production; } \\
\text { - with the exception of certain industries, } \\
\text { such as gardening, vegetable growing, } \\
\text { agriculture of the republic, it is } \\
\text { characterized by a low level of innovation; } \\
\text { - low standard of living of the rural } \\
\text { population; } \\
\text { - underdeveloped specialized agricultural } \\
\text { infrastructure, for example, seed production, } \\
\text { agrochemistry (often preference is given to } \\
\text { imported analogues), breeding, veterinary } \\
\text { medicine, etc.; } \\
\text { - the system of state support and subsidies } \\
\text { does not fully satisfy the needs of } \\
\text { agricultural producers; } \\
\text { - an underdeveloped risk insurance system } \\
\text { that meets modern conditions for organizing } \\
\text { agricultural production. }\end{array}$ \\
\hline Opportunities. & Threats: \\
\hline $\begin{array}{l}\text { - the regional agri-food market has the potential } \\
\text { for import substitution of agricultural products; } \\
\text { - development of export opportunities in some } \\
\text { sectors of the agro-industrial complex; } \\
\text { - involvement of unused land in agricultural } \\
\text { production; } \\
\text { - formation and development of an effective } \\
\text { mechanism of state support for the agricultural } \\
\text { sector at the regional level; } \\
\text { - development of production of environmentally } \\
\text { friendly products, as a result of the growing } \\
\text { demand for such products; } \\
\text { - the availability of innovative technologies, } \\
\text { advanced experience, which makes it possible } \\
\text { to increase the efficiency of agricultural } \\
\text { production. It is proposed to consider } \\
\text { innovative activity as a set of scientific, } \\
\text { technical, organizational, financial and } \\
\text { commercial measures aimed } \\
\text { commercializing the generated relevant } \\
\text { knowledge and technologies [8]; } \\
\text { - enhancing the quality of the management } \\
\text { system in agriculture; } \\
\text { - creation of conditions for enhancing the } \\
\text { quality of life, the standard of living of the rural } \\
\text { population, in order to curb migration processes } \\
\text { in rural areas. }\end{array}$ & $\begin{array}{l}\text { - high dependence of agricultural production } \\
\text { on weather conditions, as a result of which } \\
\text { the risks of natural disasters, crop failure, } \\
\text { etc. } \\
\text { - reduction in the volume of state support } \\
\text { for the agricultural sector } \\
\text { - the agri-food market (like any market) is } \\
\text { subject to market fluctuations, both in the } \\
\text { domestic and foreign markets; } \\
\text { - decrease in soil fertility, depletion of the } \\
\text { potential of land, natural, water resources, } \\
\text { due to non-observance of scientific } \\
\text { recommendations for the rational use of } \\
\text { natural resources; } \\
\text { - low level of investment attractiveness of } \\
\text { the agro-industrial complex for external } \\
\text { investors. }\end{array}$ \\
\hline
\end{tabular}

\section{Conclusions}

Analysis of the agri-food market of the Kabardino-Balkarian Republic showed the existing "strengths" and "weaknesses" in the agricultural production system of the republic, as well as revealed the possibilities for growth and development of the agri-food market in the region, revealed the potential for strengthening the competitive position of the agricultural sector in the domestic and foreign markets. However, the implementation of the "opportunities" for the development of the regional agri-food market presented in the SWOT analysis is associated with overcoming "threats" and dangers of various nature, 
without the resolution of which the effective and progressive development of the agri-food market of the Kabardino-Balkarian Republic is impossible.

\section{Acknowledgments}

The study was performed with the financial support of the Russian Foundation for Basic Research, project No. 20-010-00853A.

\section{References}

1. N. Yu. Polunina, In the collection: Statistical analysis of the socio-economic development of the constituent entities of the Russian Federation, Materials of the 5th International Scientific and Practical Conference, 249-253 (2018)

2. O. I. Vanyushina, V. N. Minat, Bulletin of Rural Development and Social Policy, 2(18), 2-9 (2018)

3. E. V. Salnikova, M. E. Otinova, Economics of Agricultural and Processing Enterprises, 10, 40-48 (2020).

4. Official site of the Federal State Statistics Service, https://stavstat.gks.ru

5. Regions of Russia, Socio-economic indexes (2019), https://rosstat.gov.ru

6. A. N. Baydakov, A. V. Nazarenko, O. N. Babkina, Kant, 4(29), 213-219 (2018)

7. E. V. Afanasyev, A. A. Bykov, S.M. Golovatyuk, AIC: Economy, management, 5, 4046 (2019)

8. N. Kh. Kairova, R. Ye. Shokumova, Z. S. Marzhokhov, REVISTA INCLUSIONES, 7, 435-451 (2020) 